Pawet Mąosa

John Paul II Catholic University of Lublin, Poland

\title{
Confessional and catechetical nature of religious education in Poland
}

\begin{abstract}
This paper aims at bringing to light a presentation of the nature of religious education in Poland. This study will therefore present a brief historical outline of religious upbringing in Poland, its current organisational regulations and the principles of religious education in schools. In our summary, we will present the level of effectiveness of religious education in Poland, and we will also explore the discussion on the reformation of religious education in Poland which is being worked upon.
\end{abstract}

\section{Keywords}

Religious education, Christian formation, Catechesis, Poland, Religious Traditions.

\section{Introduction}

The Declaration by the United Nations, the Charter of Fundamental Rights of the European Union, and internal regulations in many countries, guarantee freedom of religion and the right to bring up children in accordance with the world view espoused by their parents. This right is being realised in various ways, depending on the country, its historical circumstances and current needs. It is worth pondering the system of religious upbringing as practised in particular countries. This paper aims to present the nature of religious education in Poland. There is no doubt that, among European countries, the Polish system is one that is unique, due to its religious homogeneity, and the dominant position of the Catholic Church. 


\section{The Person and the Challenges \\ $54 \quad$ Volume 5 (2015) Number 2, p. 53-66 \\ 1. An outline of religious education in Poland}

Between the years 1795-1918 Poland did not exist on the world's maps. This was due to its partition and occupation by the Russian, Prussian (later German) and Austrian empires. These occupants strove to destroy the identity of the Polish nation. However, numerous uprisings erupted to defend it, and while many of these did not bring about any political success, they contributed to the preservation of the Polish people's national identity. The Catholic Church, as well, contributed to the survival of Polish culture and language. Following the regaining of independence in 1918, and throughout the whole inter-War period (1918-1939), religious education was present in Polish schools, regulated mainly in the Constitution of 17 March 1921 and the Concordat with the Holy See of 10 February $1925^{1}$.

In line with these agreements, religious education was a school subject obligatory for everyone who declared themselves as Catholic, and the mark acquired in religious education was placed on the graduate's school diploma - the first on the list. In addition, high-school graduates were obliged to take a final religious education exam, and the acquired mark was then shown on the certificate of secondary education completion. Primary-school students had two lessons of religious education per week, while in middle schools there was one such class weekly. The curricula of religious education were created by the Church and approved by the Government ${ }^{2}$. Religious education teachers, both clerical and secular, were treated on a par with other teaching professionals and had the right to participate in teaching-staff meetings. Moreover, the rules of their remuneration were the same as those adopted withrespect to teachers of other subjects. Furthermore, when employing a religious education teacher, educational authorities required that the candidate had obtained a canonical mission from the diocese bishop, which comprised an accolade of the Church's responsibility for the process of a religious upbringing.

Aside from systematic participation in religious education lessons at schools, children were obliged to participate in religious practices, that is in Masses, featuring a sermon, on Sundays, in three-day retreats during

\footnotetext{
1 See J. Osuchowski, Państwo ludowe a Kościót rzymskokatolicki w Polsce w latach 1944-1948, Warsaw 1981, Wydawnictwa Uniwersytetu Warszawskiego.

S. Skuza, Nauczanie religii w Polsce w świetle prawa państwowego po roku 1945, in: Nowa Ewangelizacja. The "Communio" collection 8 (1993), p. 203-265.
} 
Lent, in confession and communion (a minimum of three times), and in prayers before and after lessons ${ }^{3}$.

After World War II, a Communist Government dependent on the Soviet Union rose to power. As early as the 12 September 1945 the new Communist Government of Poland broke the Concordat of 1925, and the Church in Poland had to face increasing difficulties posed by the State. The Sejm Act of 15 July 1961 on the Development of the Education and Upbringing System brought the ultimate end to religious education at schools. This Act stated that "schools and other educational and upbringing institutions are secular establishments".

As a result, religious education began in parishes, starting from the scholastic 1961/1962. These lessons usually took place in churches, chapels, sacristies and rectories, all of which were in a very difficult financial condition. Initially, parish catechesis was subject to some shortcomings and neglect on the Church's side - an organisation which was not prepared to establish high-standard venues at short notice. Many problems were also connected with the fact that parish catechesis was not run systematically, and was often cancelled when these clashed with other pastoral services. Such a state of affairs continued until religious education saw its comeback in schools on 1 September 1990, following the overthrowing of Communist rule.

\section{Current organisational regulations}

When religious education returned to Polish schools in 1990 after 30 years of absence, there emerged a need to establish its conceptual and organisational framework. Numerous legal acts have therefore been adopted in this respect. Among these were, first and foremost, the Resolution of the Minister of National Education of 1992, on the rules and method of organising religious education in Poland and the Concordat concluded between the Holy See and the Government of the Republic of Poland, signed on 28 July 1993, ratified, due to political reasons, only on 23 February $1998^{5}$.

\footnotetext{
S. Wiecha, Kościól a wychowanie, Warsaw 1978, Wydawnictwo Ministerstwa Obrony Narodowej.

4 The Parliament of the People's Republic of Poland. Act on 15 VII 1961, on the Development of the Education System, Warsaw 1961.
}

5 The 1993 Concordat between the Holy See and the Republic of Poland, Warsaw 1993. 
In accordance with Polish Law, religious lessons comprise an optional subject in state schools, which, in practice, means that they are attended only by students whose parents wish so. Furthermore, after 18, students are free to decide on this matter themselves. Pursuant to the relevant regulations, religious-education lessons are organised in all types of schools twice a week. This situation applies to both children and young people.

In theory, students can opt for ethics lessons; however, for the time being, these are organised in a very limited number of schools. In practice, those not attending religious education lessons do not usually have any alternatives, and during religious education lessons, they return to their homes or wait for the next lesson in the school corridor. Currently, more and more schools are organising ethics lessons, yet this process appears to be fairly slow.

Polish Law, in addition, allows the option of displaying crosses and religious symbols in schools, and saying prayers before and after lessons, and it also legalises the option to excuse children from school lessons three days a year to retire to a Lent retreat so they can prepare for Easter.

Furthermore, legal regulations make it possible to place the mark obtained in religious education on school leaving diplomas; however teachers are obliged not to disclose the information on the type of lessons attended by any student (religious education or ethics). Moreover, the mark in religious education does not impact on the students' promotion to the next grade. Therefore, should a student be given an unsatisfactory mark in religious education, he or she would have still be promoted to the next grade.

\section{The principles of Catholic religious education in schools}

In the teachings of the Catholic Church, religious education in schools has a distinct identity that is different from parish catechesis. This is mentioned in such documents as the General Catechetical Directory ${ }^{6}$, the Evangelii Nuntiandi ${ }^{7}$

6 Sacred Congregation for the Clergy, General Catechetical Directory, Vatican 1971, Libreria Editrice Vaticana.

Evangelii Nuntiandi. The apostolic exhortation of His Holiness Pope Paul VI. Vatican 1975, Libreria Editrice Vaticana. 
apostolic exhortation, the Catechesi tradendae $e^{8}$ apostolic exhortation, and the General Directory for Catechesis 9 .

The General Catechetical Directory of 1971 does not, however, refer to schools directly. It merely states that "in regions which have been Christian from old, catechesis often takes the form of religious instruction given to children and adolescents in schools or outside the school atmosphere"10.

At the same time, noticing changes in religiousness, the document postulates the introduction of evangelisation elements into schools. "Very often the actual condition of large numbers of the faithful necessarily demands that some form of evangelisation of the baptised precede catechesis"11.

Pope Paul VI, in the apostolic exhortation Evangelii Nuntiandi of 1975, discusses the broadly-understood process of evangelisation, and in so doing, with respect to catechetical instruction, points to the substantial role that schools can play: "A means of evangelisation that must not be neglected is that of catechetical instruction. The intelligence, especially that of children and young people, needs to learn through systematic religious instruction the fundamental teachings, the living content of the truth which God has wished to convey to us and which the Church has sought to express in an ever-richer fashion during the course of her long history. No one will deny that this instruction must be given to form patterns of Christian living and not to remain only notional. Truly the movement towards evangelisation will benefit greatly - at the level of catechetical instruction given at church, in the schools, where this is possible, and in every case in Christian homes - if those giving catechetical instruction have suitable texts, updated with wisdom and competence, under the authority of the bishops"12.

Paul VI thus accentuates the transfer of religious knowledge, not in an inter-religious or interdenominational manner, but in a confessional depiction - referring, in this case, to Catholicism. At the same time, he is aware that the transfer of religious knowledge is not always possible in schools.

8 Catechesi Tradendae. The apostolic exhortation of His Holiness Pope John Paul II. Vatican 1979, Libreria Editrice Vaticana. Vaticana.

9 Congregation for the Clergy, General Directory for Catechesis, Vatican 1997, Libreria Editrice

10 General Catechetical Directory, n. 19.

11 General Catechetical Directory, n. 19.

12 Evangelii Nuntiandi, n. 44. 
On the other hand, Pope John Paul II, in the apostolic exhortation, Catechesi Tradendae, of 1979, accentuates the need for maintaining catechetical formation (education in faith) in schools, yet he realistically notes that this is becoming increasingly impossible. In the face of changes in religiousness, he also formulates the following postulate with respect to religious education: "I express the fervent wish that, in response to the very clear right of the human person and of the family, and out of respect for everyone's religious freedom, all Catholic pupils may be enabled to advance in their spiritual formation with the aid of religious instruction dependent on the Church, but which, according to the circumstances of different countries, can be offered either by the school or in the setting of the school, or again within the framework of an agreement with the public authorities regarding school timetables, if catechesis takes place only in the parish or in another pastoral centre. In fact, even in places where objective difficulties exist, it should be possible to arrange school timetables in such a way as to enable Catholics to deepen their faith and religious experience, with qualified teachers, whether priests or lay people"13.

In the very same document, John Paul II explains his understanding of the essence of religious teaching in schools: "Those who study are bound to bear the stamp of their studies, to be introduced to cultural or moral values within the atmosphere of the establishment in which they are taught, and to be faced with many ideas met with in school. It is important for catechesis to take full account of this effect of the school on the pupils, if it is to keep in touch with the other elements of the pupil's knowledge and education; thus the Gospel will impregnate the mentality of the pupils in the field of their learning, and the harmonisation of their culture will be achieved in the light of faith"14.

The General Directory for Catechesis of 1997 explains the Catholic concept of religious education in even more detail: "Within the ministry of the word, the character proper to religious instruction in schools and its relationship with the catechesis of children and of young people merit special consideration. The relationship between religious instruction in schools and catechesis is one of distinction and complementarity: "there is an absolute necessity to distinguish clearly between religious instruction and catechesis". What confers on religious instruction in schools its proper evangelising character is the fact that it is called to penetrate a particular area of culture and to relate to other

13 Catechesi tradendae, n. 69.

${ }_{14}$ Catechesi tradendae, n. 69. 
areas of knowledge. As an original form of the ministry of the word, it makes present the Gospel in a personal process of cultural, systematic and critical assimilation"15.

Therefore, the main task of religious education in schools is to bring about a synthesis of faith and culture, which is, to lead to developing a coherent vision of man and the world. To this end, Catholic religious education should interact with other school subjects and other branches of knowledge. Therefore, the General Directory for Catechesis postulates that: "It is necessary, therefore, that religious instruction in schools appear as a scholastic discipline with the same systematic demands and the same rigour as other disciplines. It must present the Christian message and the Christian event with the same seriousness and the same depth with which other disciplines present their knowledge. It should not be an accessory alongside these disciplines, but rather it should engage in a necessary inter-disciplinary dialogue. This dialogue should take place, above all, at the level at which every discipline forms the personality of students. In this way, the presentation of the Christian message influences the way in which the origins of the world, the sense of history, the basis of ethical values, the function of religion in culture, the destiny of man and his relationship with nature, are understood. Through interdisciplinary dialogue, religious instruction in schools underpins, activates, develops and completes the educational activity of the school"16.

The aforementioned teaching of the Catholic Church first and foremost states that the purpose of religious education in schools is to enable learners to participate in a dialogue between Christianity and contemporary culture, mainly through the transfer of genuine knowledge correlated with other school subjects. Therefore, the purpose of so-defined religious education is to shape an integral vision of the world which will be free from false dualities, such as faith-reason, religion-science, the Church-the world, etc. The above-mentioned depiction of religious education in schools is not so much to serve a catechetical and mystagogical function, but rather a teaching and upbringing function.

15 General Directory for Catechesis, n. 73.

16 General Directory for Catechesis, n. 73. 


\section{Religious education in Polish schools}

In the Polish reality, religious education takes on a particular identity. In some ways, this runs counter to the notions expressed by the Church, which merely refers to the possibilities which the authors of the General Directory for Catechesis permit, depending on local circumstances. In this matter, they state that: "Religious instruction in schools is developed in diverse scholastic contexts, while always maintaining its proper character, to acquire different emphases. These depend on legal and organisational circumstances, educational theories, and the personal outlook of individual teachers and students, as well as the relationship between religious instruction in the schools and family or parish catechesis"17.

These specific, Polish, circumstances had already been invoked by 1990 , when religion returned to schools after a thirty-years absence. The, then-adopted, model harked back to the solutions in force before religious education was discontinued by the Communist authorities, which meant the practical transfer of parish catechesis to schools, making religious communities responsible only for direct preparation for entrance into the sacraments, that is to the First Communion and Confirmation. The previously-developed model of religious education in schools could, therefore, be acknowledged as being both confessional and catechetical. The confessionality of religious education in Poland consists of the Church deciding on the content of, and the methods used in religious education. The core curriculum assumes that the whole deposit of the Catholic Faith is discussed twice - in the primary school (6 years) and in the combined middle (3 years) and secondary school (3 years).

From the very beginning of the return of religious education to schools, the Church, which in practice means the Polish Bishops' Conference, along with the input of every diocesan bishop, decided on the curricula and books used in religious education in schools, including the State ones. At the same time, religious education teachers can be employed in schools only if they acquire a special appointment from a bishop, a so-called canonical mission. On the other hand, revoking such a mission results in immediate dismissal from the school. The Catholic Church, aside from imparting education in Catholic theology, also requires from teachers that they lead a life consistent with the doctrine and morality of the Church. Thus, all religious-education teachers are

\footnotetext{
17 General Directory for Catechesis, n. 74.
} 
obliged to be not only to be teachers and educators, but also living witnesses to the Faith and towards an active life in the Church.

Therefore, the aim of religious education in Polish schools is to carry out all the functions of catechesis characteristic of ecclesiastical communities, that is teaching, upbringing and initiating into Christianity. In such a sense, there is more to it than just merely passing knowledge of religion on to students or shaping desirable social attitudes. This entails lighting up or intensifying faith, as well as introducing the regular sacramental life and the observances of the Catholic rules of morality. As we can see, religious education in Polish schools incorporates a form of catechesis as part of its principles.

The Second Plenary Synod of the Polish Church that took place in 1991-1999, when referring to religious education in schools, even uses the term "school catechesis" and adopts a stance that religious education in schools "should lead not only to acquainting oneself with Christianity, but, more importantly, to the love of God and getting close to Him"18. On the other hand, the Catechetical Directory of the Catholic Church in Poland, in the section devoted to religious education in state schools, puts forward the following: "In Polish conditions, if we take into account the historical circumstances and the catechetical tradition that has been strengthened for the last decades, we should treat religious education in schools as part of catechesis, i.e. its specific form"19.

The aforementioned findings entail serious consequences, which consist mainly of the Church's treating religious education in Polish schools fundamentally on a par with catechesis.

The main principle, on the basis of which religious education in Polish schools functions, is the principle of auxiliarity. This means that the State is obliged to aid parents in upbringing their children, in its religious aspect, in line with their beliefs. This principle stems from the basic human right of the freedom to practise religion. All schools in Poland, including State schools, therefore organise religious education for children in accordance with their parents' will, or the wishes of young people themselves, if they are adults.

This means that the confessional and catechetical nature of religious education, and the connected responsibility of the Church in relation to the content and

18 II Polski Synod Plenarny 1991-1999. Poznań 1999, Pallotinum, p. 51; P. Tomasik, Religia $w$ dialogu z edukacja. Studium na temat korelacji nauczania religii katolickiej z polska edukacja szkolna, Warsaw 2004, Wydawnictwo Salezjańskie, p. 150.

19 Konferencja Episkopatu Polski, Dyrektorium Katechetyczne Kościoła katolickiego w Polsce, Kraków 2001, WAM, n. 82. 
forms of its teaching, does not exclude the responsibility of schools. This notion is explained in the Catechetical Directory of the Catholic Church in Poland in the following way: "In religious education in schools, the subjective nature is maintained both by the Church and the school. Therefore, religious education in schools should carry out the tasks imposed on it, as well as the selected goals defined by the school. The relationship between religion and school can be expressed both by the correlation of subordination and autonomy. Subordination means here first and foremost the inclusion of a school catechist into responsibility for the implementation of the education and didactic plan of a given school" 20 .

The aforementioned stance means, in practice, that religious education is subject to pedagogical supervision similar to other subjects, which, however, applies only to the methodology of teaching and to curricular compliance. As we have mentioned before, the curriculum and books are compiled and authorised by the Church. State Authorities are then informed about these, but cannot reject them.

At the same time, religious education is treated on a par with other subjects, and the mark in religious education is reflected in the mark average. This is also connected with the convention that evaluation criteria in schools do not take into account religious practices, but rather concern students' knowledge of and involvement in the religious education lessons taught in school. From the status of religious education in Polish school, it follows that local-government bodies that maintain a school are obliged to put religious education lessons into the school's lesson plan, to fund their functioning, and to supervise them in respect of conformity with the curriculum and the application of the appropriate methods. In turn, religious education realises the fundamental parents' and children's right to a religious upbringing, and also influences the whole school reality, mainly with respect to the axiological level.

The vast majority of children and young people in Poland participate in religious education. According to some studies "Roman Catholic RE is predominant in kindergartens (94.7 percent), primary schools (98.0 percent), lower high schools (97.1 percent), technical high schools (92.6 percent), and grammar schools (9.1 percent)"21. Yet, the participants in religious education

${ }^{20}$ Konferencja Episkopatu Polski, Dyrektorium Katechetyczne Kościoła katolickiego w Polsce, Kraków 2001, WAM, n. 82.

${ }^{21}$ K. Zielińska \& M. K. Zwierżdżyński, Religious Education in Poland, in: Derek Davis \& Elena Miroshnikova (Eds.), The Routledge International Handbook of Religious Education, London 2012, Routledge, p. 264-271. 
lessons demonstrate a highly-diversified level of religiousness. The General Directory for Catechesis enumerates three types of people to whom religious education is addressed, i.e., the believers, those who are searching or who have religious doubts, and non-believers. Religious education assists the believers in understanding better the Christian message by relating it to their great existential concerns. For students who are searching, or who have religious doubt, it is intended to aid them in finding, within religious instruction, the possibility of discovering what faith in Jesus Christ is, and what response the Church makes to their questions. With regard to students who are non-believers, but who participate in religious-education lessons (which are then of a missionary nature), the intention is to ignite their faith ${ }^{22}$.

All the aforementioned types of students participate in religious-education lessons in Polish schools. Nevertheless, we have to admit that the theoretical principles of religious education in Polish schools are not accurate. It is assumed that they are, at the same time, a form of catechesis, which, by its nature, is addressed only to believers and aims at not only teaching and upbringing, but also at initiating them into being a Christian. On the other hand, however, it is assumed that participants in religious education include those who are religiously indifferent, as well as those who are non-believers. In both such groups, the realisation of this initiating function is particularly difficult $t^{23}$. This peculiar lack of consequence can be understandable if we take into account that, in Poland, the school is practically the only environment in which systematic Christian instruction and formation is being carried out. Though we can speak of parish catechesis, it has been basically reduced to providing direct preparation for the sacraments.

\section{Discussion on reforming religious education in Poland}

As we have already mentioned, the concept of religious education in Poland assumes that it is a form of catechesis and should lead not only to obtaining specific knowledge, but also to the deepening of faith, to adopting Catholic

22 General Directory for Catechesis, n. 61.

${ }^{23}$ P. Tomasik, Koncepcja nauczania religii w nowych dokumentach katechetycznych Kościoła polskiego, in: Przesłanie dokumentów katechetycznych Kościoła w Polsce, S. Dziekoński (Ed.), Warsaw 2003, Verbinum, p. 240. 
morality and to participating in the liturgy. Aside from religious education, a kind of catechesis is also organised in parish, which aims at preparation for sacraments and introduction into the community of the Church. In practice, it turns out that these aims are pursued to a limited extent.

The results of empirical research conducted over recent years corroborate that ca. $90 \%$ of young people in Poland consider themselves members of the Roman Catholic Church. According to the research conducted by J. Mariański, $34.1 \%$ of young people in Poland also systematically participate in religious practices, while $34.4 \%$ do so unsystematically, $20.7 \%$ scarcely, and $7.1 \%$ do not participate at all ${ }^{24}$. We should also notice an evident downward trend in the group of young people who consider themselves systematically-participating believers. In 1992, this group included as many as 70\% of all young Poles. In two decades' time, we have witnessed a decrease amounting to more than $20 \%{ }^{25}$. Despite the fact that religious education in Poland takes place starting from kindergarten to the Matura exam, twice a week, the knowledge of religion of young Poles leaves much to be desired. Their religious ignorance applies to even the most fundamental matters. The following numbers can serve as an example here. Only $37.1 \%$ of young people can correctly list the names of all seven Catholic sacraments, and $25.6 \%$ of them cannot indicate even one of those, and the rest can indicate only some of the sacraments ${ }^{26}$.

In the face of the unsatisfactory efficiency displayed by the entire system of religious education and formation in Poland, its reform has been advocated. Among the main postulates for religious education at school is to focus on preevangelisation and evangelisation in their strict sense. Pre-evangelisation should, first and foremost, consist of enabling learners to search for the objective truth about the world and about humanity, and also empowering them to analyse the positive and negative personal experiences met by all human beings, such as love, friendship, and beauty, as well as loneliness and suffering ${ }^{27}$. These, in their

24 J. Mariański, Emigracja z Kościoła. Religijność młodzieży polskiej w warunkach zmian społecznych, Lublin 2008: Wydawnictwo KUL, p. 127.

25 P. Mąkosa, The Catholic Identity of Polish Youth at the Beginning of the 21st Century, in: A Glance in the Mirror. Dutch and Polish religious cultures. Kalsky, M. \& P. Nissen. Münster - Berlin -Wien - London 2012, LIT Verlag, p. 83.

26 J. Mariański, Emigracja z Kościoła. Religijność młodzieży polskiej w warunkach zmian społecznych, Lublin 2008: Wydawnictwo KUL, p. 224.

27 P. Mąkosa, Preewangelizacja pierwszym i koniecznym etapem formacji chrześcijańskiej, "Katecheta" 54:2010, vol. 7-8, pp. 25-34. 
core, concern the meaning of life. Therefore, it is proposed that the beginning of Christian formation focus not only on matters of faith, but more importantly on philosophical arguments concerning the meaning of human existence. The intention of so doing is to spur on a reflection on the fundamental dilemmas of the human being and preparing the basis for the Christian faith.

Next, it is proposed to propagate the basic Christian kerygma instead of teaching complex dogmas and detailed moral rules. The essence of this is God's love for humanity expressed in the history of salvation, in the centre of which there is Jesus Christ. The kerygma means passing on the most fundamental information, and not the whole deposit of faith.

\section{Bibliography}

Sacred Congregation for the Clergy, General Catechetical Directory. Vatican 1971, Libreria Editrice Vaticana.

CatechesiTradendae. The apostolic exhortation of His Holiness Pope John Paul II. Vatican 1979, Libreria Editrice Vaticana.

Evangelii Nuntiandi. The apostolic exhortation of His Holiness Pope Paul VI. Vatican 1975, Libreria Editrice Vaticana.

Congregation for the Clergy, General Directory for Catechesis, Vatican 1997, Libreria Editrice Vaticana.

The Second Polish Plenary Synod 1991-1999. Poznań 1999, Pallotinum.

The Constitution of the Republic of Poland of 1921, Warsaw 1921.

The 1925 Concordat between the Holy See and the Second Polish Republic, Warsaw 1925.

The 1993 Concordat between the Holy See and the Republic of Poland, Warsaw 1993.

Mąkosa P., Preewangelizacja pierwszym i koniecznym etapem formacji chrześcijańskiej [PreEvangelisation as the First and Necessary Stage of Christian Formation], "Katecheta" 54 (2010), vol. 7-8, p. 25-34.

Mąkosa P., The Catholic Identity of Polish Youth at the Beginning of the 21st Century, in: A Glance in the Mirror. Dutch and Polish religious cultures. Kalsky, M. \& P. Nissen. Münster - Berlin - Wien - London 2012, LIT Verlag, p. 79-90.

Mariański J., Emigracja z Kościoła. Religijność młodzieży polskiej w warunkach zmian spolecznych [Leaving the Church. The Religiousness of Young People in Poland in the Face of Social Chainges], Lublin 2008, Wydawnictwo KUL.

Osuchowski J., Państwo ludowe a Kościót rzymskokatolicki w Polsce w latach 1944-1948 [A People's State and the Roman Catholic Church in Poland in 1944-1948], Warsaw 1981, Wydawnictwa Uniwersytetu Warszawskiego.

Polish Bishops' Conference, Dyrektorium Katechetyczne Kościoła katolickiego w Polsce [The Catechetical Directory of the Catholic Church in Poland], Kraków 2001, WAM. 
Skuza S. Nauczanie religii w Polsce w świetle prawa państwowego po roku 1945 [Religious Education in Poland in the Light of State Law after 1945], in: Nowa Ewangelizacja. The "Communio" collection 8 (1993), p. 203-265.

The parliament of the People's Republic of Poland, Act on 15 VII 1961, on the Development of the Education System, Warsaw 1961.

Tomasik P., Koncepcja nauczania religii w nowych dokumentach katechetycznych Kościoła polskiego [The Concept of Religious Education in New Catechetical Documents of the Polish Church], in: Przesłanie dokumentów katechetycznych Kościoła w Polsce [The Message of Catechetical Documents of the Church in Poland]. S. Dziekoński (Ed.), Warsaw 2003, Verbinum.

Tomasik P., Religia $w$ dialogu z edukacja. Studium na temat korelacji nauczania religii katolickiej z polska edukacja szkolna. [Religion in Dialogue with Education. A Study on the Correlation between Teaching the Catholic Faith and Polish School Education], Warsaw 2004, Wydawnictwo Salezjańskie.

Wiecha S. Kościót a wychowanie [The Church and Upbringing], Warsaw 1978, Wydawnictwo Ministerstwa Obrony Narodowej.

Zielińska K. \& Zwierżdżyński M. K., Religious Education in Poland, in: Derek Davis \& Elena Miroshnikova (Eds.), The Routledge International Handbook of Religious Education, London 2012, Routledge, p. 264-271. 